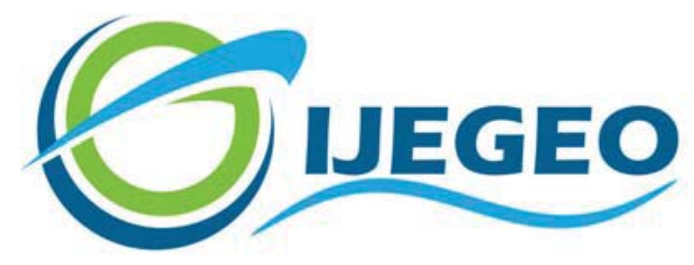

International Journal of Environment and Geoinformatics (IJEGEO) is an international, multidisciplinary, peer reviewed, open access journal.

\title{
Mucilage Problem in the Semi-Enclosed Seas: Recent Outbreak in the Sea of Marmara
}

\section{Başak SAVUN-HEKİMOĞLU, Cem GAZIOĞLU}

\author{
Chief in Editor \\ Prof. Dr. Cem Gazioğlu \\ Co-Editors
}

Prof. Dr. Dursun Zafer Şeker, Prof. Dr. Şinasi Kaya,

Prof. Dr. Ayşegül Tanık and Assist. Prof. Dr. Volkan Demir

\author{
Editorial Committee (December 2021)
}

Assoc. Prof. Dr. Abdullah Aksu (TR), Assit. Prof. Dr. Uğur Algancı (TR), Prof. Dr. Bedri Alpar (TR), Assoc. Prof. Dr. Aslı Aslan (US), Prof. Dr. Levent Bat (TR), Prof. Dr. Paul Bates (UK), İrşad Bayırhan (TR), Prof. Dr. Bülent Bayram (TR), Prof. Dr. Luis M. Botana (ES), Prof. Dr. Nuray Çağlar (TR), Prof. Dr. Sukanta Dash (IN), Dr. Soofia T. Elias (UK), Prof. Dr. A. Evren Erginal (TR), Assoc. Prof. Dr. Cüneyt Erenoğlu (TR), Dr. Dieter Fritsch (DE), Prof. Dr. Çiğdem Göksel (TR), Prof.Dr. Lena Halounova (CZ), Prof. Dr. Manik Kalubarme (IN), Dr. Hakan Kaya (TR), Assist. Prof. Dr. Serkan Kükrer (TR), Assoc. Prof. Dr. Maged Marghany (MY), Prof. Dr. Michael Meadows (ZA), Prof. Dr. Nebiye Musaoğlu (TR), Prof. Dr. Masafumi Nakagawa (JP), Prof. Dr. Hasan Özdemir (TR), Prof. Dr. Chryssy Potsiou (GR), Prof. Dr. Erol Sarı (TR), Prof. Dr. Maria Paradiso (IT), Prof. Dr. Petros Patias (GR), Prof. Dr. Elif Sertel (TR), Prof. Dr. Nüket Sivri (TR), Prof. Dr. Füsun Balık Şanlı (TR), Prof. Dr. Uğur Şanlı (TR), Duygu Ülker (TR), Prof. Dr. Seyfettin Taş (TR), Assoc. Prof. Dr. Ömer Suat Taşkın (TR), Assist. Prof. Dr. Tuba Ünsal (TR), Dr. Manousos Valyrakis (UK), Dr. İnese Varna (LV), Dr. Petra Visser (NL), Prof. Dr. Selma Ünlü (TR), Assoc. Prof. Dr. Oral Yağcı (TR), Prof. Dr. Murat Yakar (TR), Assoc. Prof. Dr. İ. Noyan Yılmaz (AU); Assit. Prof. Dr. Sibel Zeki (TR) 


\title{
Review Article
}

\section{Mucilage Problem in the Semi-Enclosed Seas: Recent Outbreak in the Sea of Marmara}

\author{
Başak Savun-Hekimoğlu* (iD), Cem Gazioğlu \\ Institute of Marine Sciences and Management, İstanbul University, İstanbul, Turkey \\ * Corresponding author: B. Savun-Hekimoğlu \\ E-mail: basak.savun@istanbul.edu.tr
}

Received: 21.05 .2021

Accepted: 22.06.202

How to cite: Savun-Hekimoğlu, B. and Gazioğlu, C. (2021). Mucilage Problem in the Semi-Enclosed Seas: Recent outburst in the Sea of Marmara. International Journal of Environment and Geoinformatics (IJEGEO), 8(4):402-413. DOI: 10.30897/ijegeo.955739

\begin{abstract}
Mucilage is an exopolymeric organic substance that occurs in the marine environment due to the overgrowth of a type of sea algae. Extreme blooms of algae are often triggered by rising seawater temperatures and human-induced pressures such as domestic and industrial wastes, insufficient treatment levels, excessive fishing. In semi-enclosed seas, this phenomenon creates growing concern, as it has a detrimental impact on the entire ecology, particularly benthic organisms. The Sea of Marmara is filled for months with mucilage that clogs the networks of fishers, suffocates marine life, and threatens tourism and the economy. Although the mucilage did not occur in the Sea of Marmara for the first time, nor is the occurrence unique to the area, it is thought to be one of the worst mucilage outbreaks ever. This study aims to provide information on the possible causes and consequences of mucilage and related research in the Sea of Marmara.
\end{abstract}

Keywords: Mucilage, Enzymatic activity, the Sea of Marmara, Nutrients, Organic matter

\section{Introduction}

Marine mucilage, also known as sea snot or marine snow, is a mucus-like particulate organic substance found in the sea (Precali et al., 2005). Phytoplankton, which is the first step of biological production in the sea, mucilage into seawater when proliferates with the trigger of some environmental factors. Mucilage is an occasionally or repeatedly occurring global phenomenon in several coastal areas. It has taken place in the Mediterranean Sea, Ariake Sound in West Japan, Tasman Bay and near the Pacific coast in the USA (Alldredge and Crocker, 1995; Fukao et al., 2009; MacKenzie et al., 2002; Danovaro et al., 2009; Lancelot, 1995). The first event was recorded in the scientific literature in the North Adriatic Sea in 1729 (Umani et al., 2007). Worldwide studies show that multiple triggers are present for marine mucilage. Abiotic causes include the climatic, anthropogenic pressures, and associated nutrient concentration variations in seawater, whereas the microbial response to these change conditions is a consequence of biotic factors (Cozzi et al., 2004; De Lazzari et al., 2008; Flander-Putrle and Malej, 2008).

Marine organisms release mucilage via various mechanisms, including phytoplankton exudation of photosynthetically-derived carbohydrates produced under stressful conditions and death and decomposition of cell-wall debris (Danovaro et al., 2009). This can be compounded by prokaryotes' poor ability to hydrolyze these exopolymers via extracellular enzymes, resulting in the release of high molecular weight compounds in the system (Danovaro et al., 2009; Bidle and Azam, 1998). These processes can be linked to prokaryotic and phytoplankton viral infections and the associated cell lysis (viral shunt), thus contributing further to the release and accumulation of organic dissolved matter into the water column (Danovaro et al., 2009; Peduzzi and Weinbauer, 1993).

The role of bacteria in forming long-lasting dissolved and colloidal polysaccharides is complex, diverse, and prominent, according to Azam (1998). The bacteria interactions with marine snow are modeled by Kiørboe and Jackson (2001). Their results showed that organic matter-consuming bacteria abound in the upper ocean, reaching densities of about $10^{6}$ per $\mathrm{ml}$; however, dissolved molecules can only be absorbed (Kiørboe and Jackson 2001; Azam and Long, 2001).

The results of previous studies indicate that bacteria in seawater can sense chemical gradients and are attracted to nutrient molecules (Azam and Long 2001). Hence, organic particle attracted bacteria intensely colonize $\left(10^{9}\right.$ per $\mathrm{ml}$ densities) and produce extracellular enzymes whose activity releases and breaks down elements such as proteins and polysaccharides. The organic material in the upper sea is thus conserved as non-sinking dissolved organic matter (DOM). However, because the invading bacteria generate DOM far rapidly than they can use it, the sinking marine snow leaves a nutrient-rich plume behind it. Protozoa that eat bacteria and larger animals that eat protozoa would be attracted to these plumes. The plumes might thus become the focus of complex ecosystems (Azam and Long, 2001). Figure 1 represents carbon fluxes in the ocean in the presence of marine snow. It is seen that marine snow can sink into the deep ocean removing it from the upper sea or become 
involved in the nutrient cycle. The first process is bacterial colonization, which generates enzymes that transform marine snow into dissolved organic materials. The sinking snow releases a plume of carbon, nitrogen, silicon and iron bearing material. The production of DOM is therefore faster than it can be used. The plume is attracted to fast-growing bacteria (red) (Figure 1).

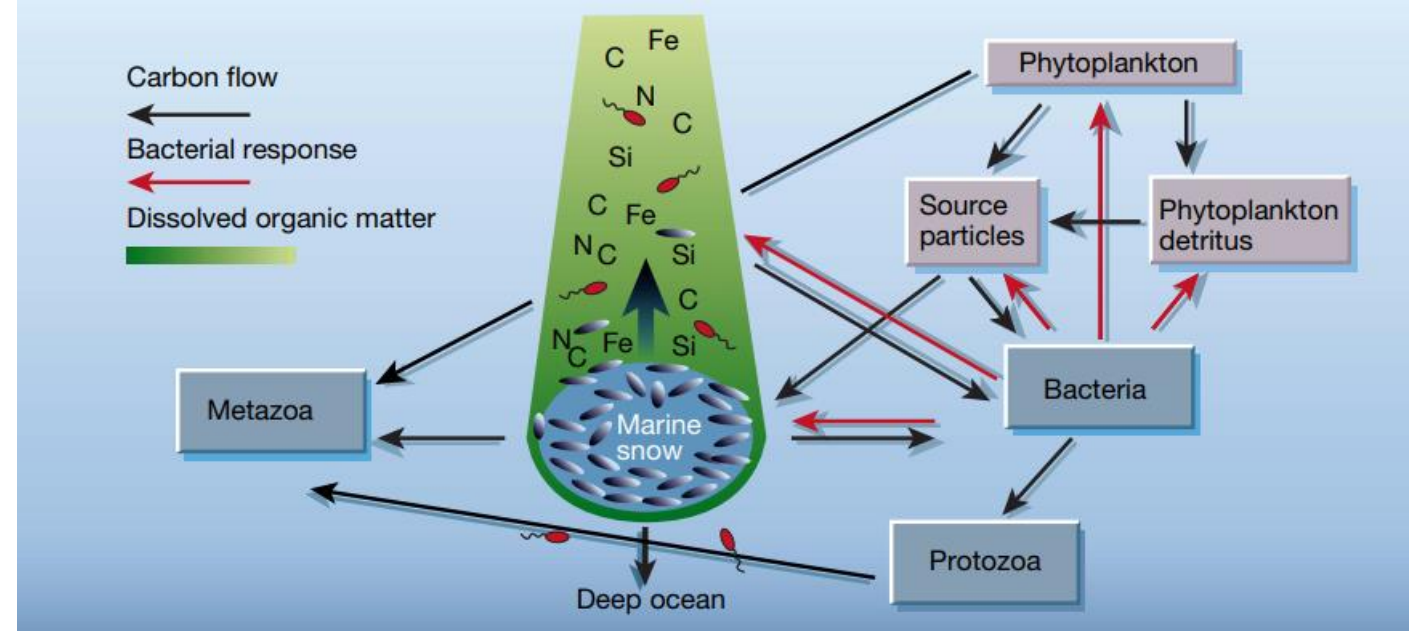

Fig. 1. Ocean carbon flows in the presence of marine snow (Azam and Long, 2001).

\section{Mucilage as marine diseases carriers}

Usually, the mucilage itself is harmless, but it can attract bacteria and viruses. A wide range of species, from little phytoplanktons to huge zooplanktons, planktons, and detrital particles suspended in the water column, may be retained in mucilage. Danovaro et al. (2009) investigated the potential of mucilage to host new microbial diversity and/or spread marine diseases. They observed that marine mucilage included a broad microbial diversity and contained pathogenic species absent in surrounding seawater. Furthermore, their data show that marine mucilage is a significant repository for prokaryotes and viruses with concentration factors ranging from 103 to 104 (the ratio of abundance in mucilage to abundance in seawater per unit volume). The authors attributed the enormous quantity of prokaryotes and viruses within the mucilage to these massive aggregates being able to entrap free-living viruses and prokaryotes in the water column. Figure 2 represents the abundance of viruses and prokaryotes in mucilage and seawater samples collected from the coastal waters of the Adriatic Sea in 2007 (Danovaro et al., 2009).

In another study, Negro et al. (2005) investigated the composition and microbial dynamics of the aggregates collected during spring-summer mucilage events in the North Adriatic Sea in 2000, 2001, and 2002. Their findings (summarized in Table 1) shown that the bacterial abundance was higher in aggregates and porewater than in the surrounding water. In addition, as previously reported by Herndl et al. (1988) and Simon et al. (2002), the size of the bacteria in aggregates, porewater, and especially clouds was larger than freeliving bacteria in the surrounding water due to more favorable nutritive conditions. Moreover, the abundance of virus-like particles (VLPs) in aggregates was 300 times higher than in the surrounding water, with an average of $9.10^{11}$ VLP $\mathrm{L}^{-1}$ (Table 1). Obviously, mucilage is a symptomatic response to direct and indirect anthropogenic effects by the marine ecosystem and, secondly, a potentially growing carrier of viruses and bacteria, including pathogenic forms hazardous to human health and marine species.

Table 1. Microbial abundance in surrounding seawater, porewater and marine mucilage (Negro et al., 2005).

\begin{tabular}{|l|l|l|l|}
\hline & $\begin{array}{l}\text { Virus } \\
\mathbf{( 1 0}^{\mathbf{1 0}} \text { Virus- } \\
\text { like particles } \\
\left.\mathbf{L}^{-\mathbf{1}}\right)\end{array}$ & $\begin{array}{l}\text { Bacteria } \\
\mathbf{( 1 0}^{\mathbf{9}} \\
\left.\text { cells L }^{-\mathbf{1}}\right)\end{array}$ & $\begin{array}{l}\text { Virus: } \\
\text { Bacteria } \\
\text { ratio }\end{array}$ \\
\hline $\begin{array}{l}\text { Surrounding } \\
\text { water }\end{array}$ & 0.3 & 0.7 & 4.7 \\
\hline Porewater & 25.7 & 88.9 & 2.9 \\
\hline Mucilage & 92.2 & 87.9 & 72.0 \\
\hline
\end{tabular}

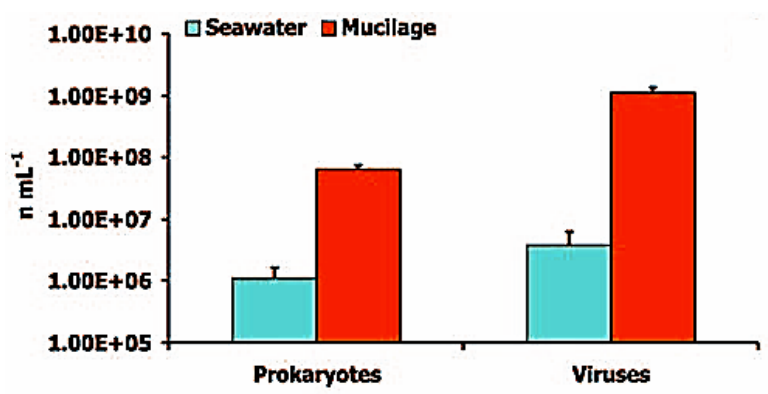

(a)

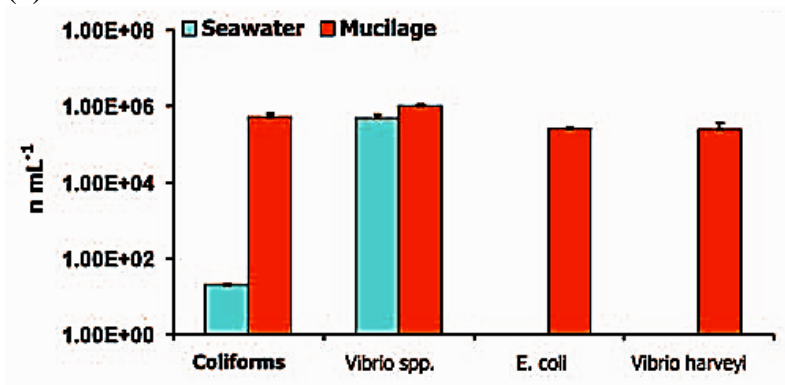

(b)

Fig. 2. The abundance of viruses and prokaryotes (a) and the number of pathogens (b) in the samples from coastal waters of the Adriatic Sea in 2007 (Danovaro et al., 2009). 


\section{Mucilage events observed around the world}

Mucilage formations in the seas are not a new phenomenon; they were first observed in 1729 off the coast of Italy (Bianchi, 1746). The mucilage event in 1729 shows that sea pollution is not the sole cause (Rinaldi and Vollenwider, 1995). Much scientific research has been conducted in the Adriatic and Tyrrhenian seas (Funari and Ade, 1999; Rinaldi et al., 1995; Gigliotti, 2013; Giani et al., 2005; Kraus and Supic, 2015). There are a limited number of recent studies in the world on monitoring mucilage formation and movements in the seas with remote sensing technology and making temporal and spatial determinations (Zambianchi, 1992; Tassan, 1993; Berthon and Zibordi, 2000; Gigliotti, 2013). While mucilage events were observed only in the Adriatic Sea before 1920, they have also started to be reported in the Aegean Sea and the Tyrrhenian Sea since 1980. The mucilage events observed in the Mediterranean and its surroundings since the 1800s are chronologically presented by Danovaro et al. (2009) (Figure 3).

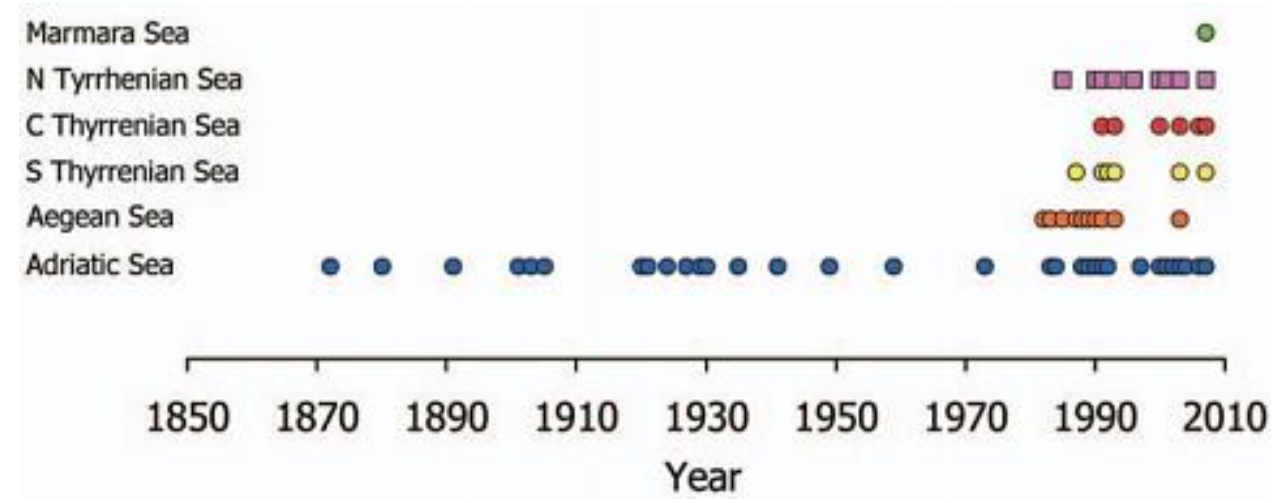

Fig. 3. Mucilage events reported in and around the Mediterranean until 2007 (Danovaro et al., 2009).

Between 1988 and 1991, Rinaldi et al. (1995) made important determinations by making measurements and observations in the Adriatic Sea. Nutrients in the water were measured in addition to the physical-chemical parameters of the seawater. According to these findings, the persistent, slightly foamy lines produced on the surface by a moving boat can be used to detect the approaching formation of mucilages before they become visible. It changes in size and shape over time, generating threads (10-30 cm long) and later clouds (from a few $\mathrm{cm}$ to $2-3 \mathrm{~m}$ ). Most of the mucilage floats several meters below the surface, disrupted by currents and turbulence. Lancelot (1995) studied the reasons for the intense mucilage event in the North Sea's Dutch coastal areas in May 1988 and found Phaeocystis overgrowth to be the primary cause. Between July 1982 and September 1993, Gotsis-Skretas (1995) reported 23 mucilage events on the Greek coast. The direct relationship between mucilage and eutrophication, which usually occurs in the summer months in coastal and gulfs with low pollution levels, has not been established, so it has been revealed that there is a complex relationship. Mecozzi et al. (2005) show that mucilage formation occurs when the organic matter degradation phase becomes slower than the synthesis phase. On the other hand, Precali et al. (2005) defined mucilages as ten different species according to their shape and color due to their observations with underwater video cameras in the northern Adriatic Sea between 1999-2002 (Figure 4). They found that small-sized mucilages (e.g. flocs, macroflocs, long structures) are more common in autumn and winter, but occur in all seasons, while largesized mucilages (e.g. cobweb, clouds, false ground) are more common in late spring and summer.

\section{Mucilage phenomenon in the Sea of Marmara}

The Sea of Marmara is between the Black Sea and the Aegean Sea, with saline (up to $40 \%$ ) lower layer from the Mediterranean Sea overlain by brackish waters $(\sim 20 \%$ ) from the Black Sea. The system is permanently stratified, with the İstanbul and Çanakkale Straits and the coastal embayment, and shifts from mesotrophic to eutrophic conditions depending on location and season (Tüfekçi et al. 2010). The Marmara ecosystem, which comprises biological components from both seas, is unique (İşinibilir-Okyay et al., 2015). Özsoy et al. (2016) comprehensively discussed the biodiversity of the Marmara Sea, aquaculture, conservation and management strategies (Özsoy et al. 2016).

Measurements were taken at 45 hydrographic sites between July 31 and August 15, 2007, as part of the project to monitor the Changing Oceanographic Conditions of the Marmara Sea. Mucilage formation was attributed to "the increase in the number of individuals of existing species as a result of the degradation of species diversity" in the project report, and it was stated that the mucilage aggregate formation in September 2007 was caused by a large-scale algal bloom (Artüz, 2008). The project's final report covers the short- and long-term measures to be taken. Yilmaz (2015) used data from stations in the northern Marmara Sea to evaluate differences in the zooplankton population during the Liriope proliferation and mucilage event. According to their data, the winter months of 2007 were warmer than typical, and the most significant change observed in the Marmara Sea during and before the mucilage period was increased Liriope production. The study examined at the 
chlorophyll a distribution in SeaWIFS satellite images and temperature changes in MODIS images. From October 2008 to August 2009, Yentur et al. (2013) noticed the mucilage phenomenon in the Dardanelles

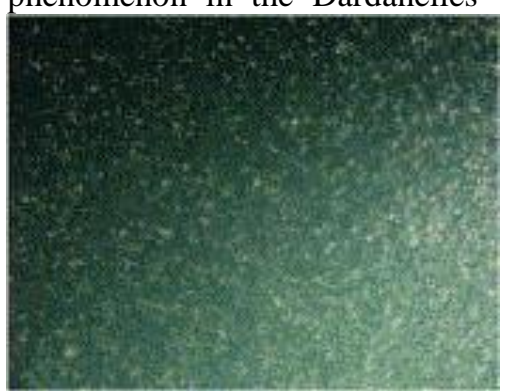

Flocs $(0,5 \mathrm{~mm}-1 \mathrm{~cm})$

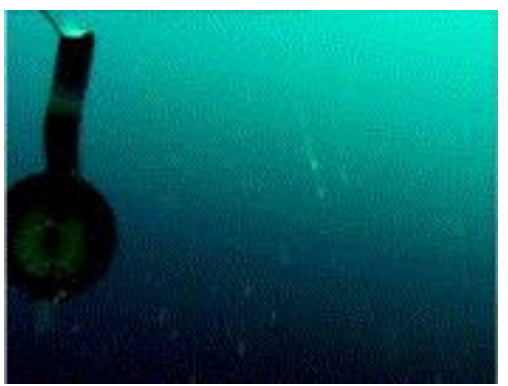

Stringers $(2-25 \mathrm{~cm})$

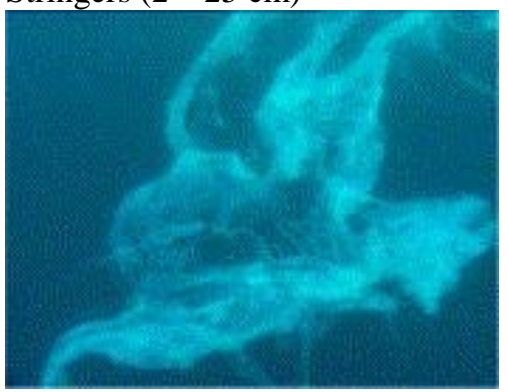

Cobweb

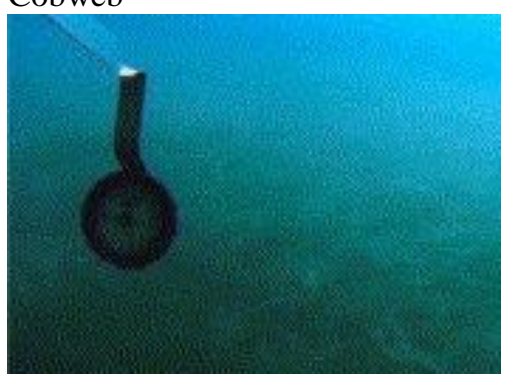

False bottom

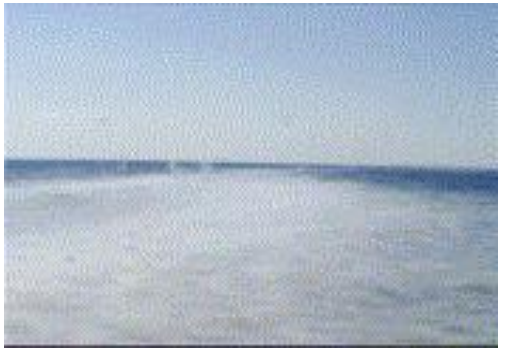

Creamy surface layer
Strait and its near surroundings in the Sea of Marmara (Yentur et al. 2013). The last mucilage event before the outbreak in 2021 was reported by Özalp (2021) in December 2020 in the Dardanelles.

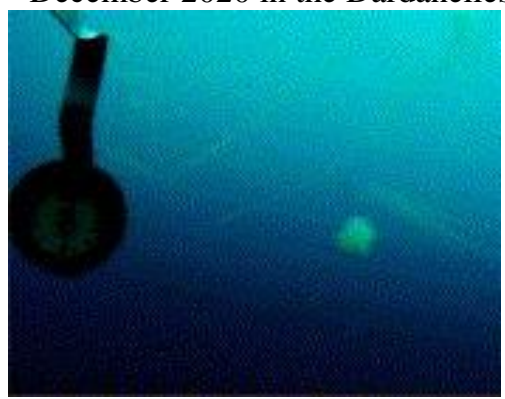

Macroflocs (1-5 cm)

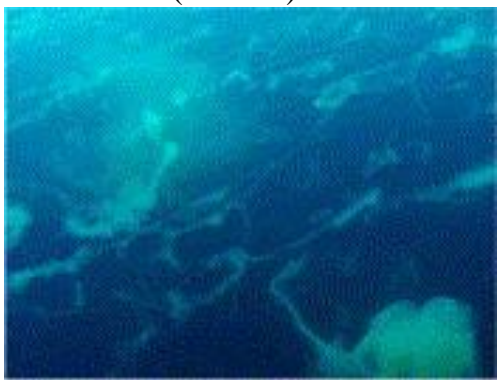

Ribbons $(10-20 \mathrm{~cm})$

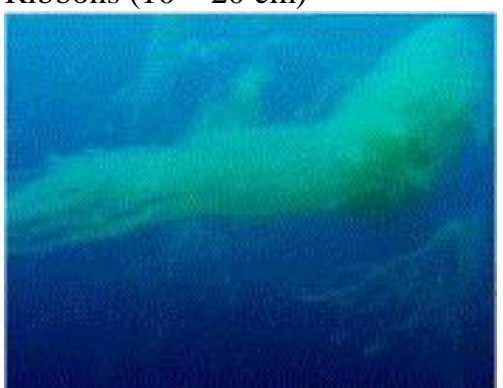

Clouds $(0,5-4 \mathrm{~m})$

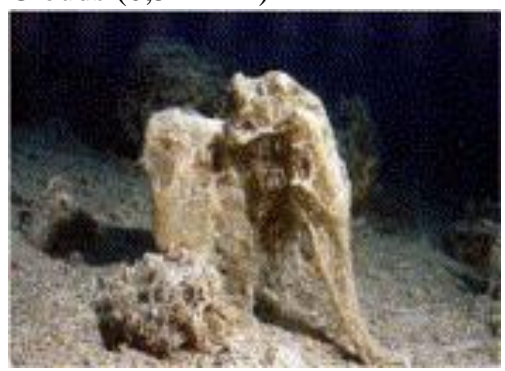

Blanket

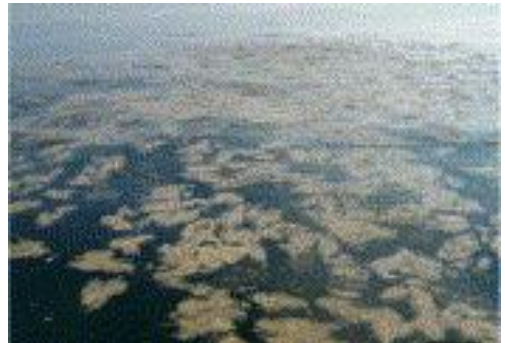

Gelatinous surface layer

Fig. 4. Mucilage types observed in the North Adriatic Sea (Precali et al. 2005).

Over the last six months, the mucilage that has covered the Sea of Marmara has attracted the whole world's attention. In 2007, mucilage was observed for the first time in the Sea of Marmara (Aktan et al., 2011). The photograph below (Figure 5) was captured during a field research by the Istanbul University Institute of Marine
Sciences and Management in the Sea of Marmara with the R/V Alemdar II Research Vessel to investigate the problem.

Some of the environmental conditions that trigger the formation of mucilage can be listed as follows: i) the 
presence of excess nutrients (nitrogen and phosphorus), ii) high temperature, and iii) stagnant sea conditions (Danovaro et al., 2009; Rinaldi et al., 1995; Volterra et al., 2000).

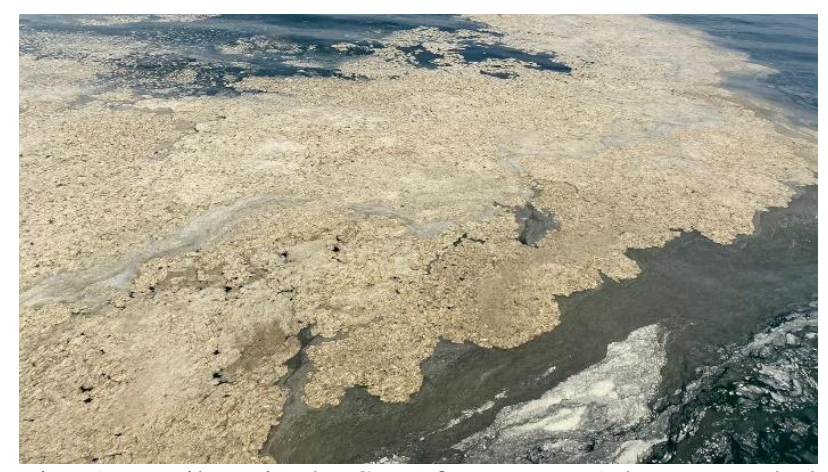

Fig. 5. Mucilage in the Sea of Marmara (Photo: Istanbul University, Institute of Marine Sciences and Management).

In Turkey, the Marmara region ranks top in terms of population density and economic activity. As a result, cities' wastewater, waste load, and pollution are all increasing due to rapid population growth (Burak et al., 2009). The Sea of Marmara is surrounded by five metropolitan municipalities and two provincial municipalities, most of which treat their wastewater physically to separate coarse and fine particulates. Then, using a liquid waste disposal process called deep-sea discharge, these effluents enter the Sea of Marmara (Burak et al., 2021). This method attempts to take advantage of the sea's inherent dilution and cleansing processes. Wastewater is piped and diffused to the seabed at various distances from the shoreline. Decarbonization plants and advanced biological treatment facilities do exist; however, they are in the minority (Maryam and Büyükgüngör, 2017). Many studies have shown that this "deep discharge" practice has caused an excess of the nutrient load that exceeds the capacity of the Marmara's marine ecosystem (Okuş et al., 2002; Taş et al., 2016; Çardak et al., 2015). Number and type of wastewater treatment plants in the region are given in the Table 2 .

Table 2. Number and type of wastewater treatment plants in the region are given in the Table 2 (Adapted from Maryam and Büyükgüngör, 2017)

\begin{tabular}{|c|c|c|c|c|}
\hline City & $\begin{array}{ll}\text { Number } & \text { of } \\
\text { Wastewater } & \\
\text { Treatment Plants } & \end{array}$ & $\begin{array}{l}\text { Type and Number of } \\
\text { Wastewater } \\
\text { Plants }\end{array}$ & Wastewater Reuse & Basin \\
\hline Bursa & 14 & $\begin{array}{l}\text { Physical Treatment Deep } \\
\text { Sea Discharge (3) } \\
\text { Secondary Treatment (4) } \\
\text { Advanced Treatment (1) }\end{array}$ & - & Marmara \\
\hline Çanakkale & 13 & $\begin{array}{l}\text { Secondary Treatment (10) } \\
\text { Advanced Treatment (1) }\end{array}$ & - & Marmara \\
\hline Edirne & 6 & Secondary Treatment (1) & Agricultural irrigation & Marmara \\
\hline İstanbul & 18 & $\begin{array}{l}\text { Advanced Treatment (5) } \\
\text { Secondary Treatment (4) } \\
\text { Pre-treatment Deep Sea } \\
\text { Discharge (9) } \\
\text { Constructed wetlands (1) }\end{array}$ & $\begin{array}{l}\text { Riva stream preservation, industrial } \\
\text { processes (cooling), landscape } \\
\text { irrigation }\end{array}$ & $\begin{array}{l}\text { Marmara } \\
\text { West } \\
\text { Black Sea }\end{array}$ \\
\hline Kocaeli & 16 & $\begin{array}{l}\text { Secondary Treatment (9) } \\
\text { Advanced Treatment (1) }\end{array}$ & - & Marmara \\
\hline Tekirdağ & 5 & Secondary Treatment (4) & - & Marmara \\
\hline Yalova & 5 & $\begin{array}{l}\text { Advanced Treatment (1) } \\
\text { Secondary Treatment (4) }\end{array}$ & - & Marmara \\
\hline
\end{tabular}

Circulations in the Sea of Marmara are mostly related to the amount of water coming from the Black Sea. In June, the water inflow from the Bosphorus to the Sea of Marmara is at its highest, and in October, it is at its lowest. By the end of October, the sea conditions have stabilized, and mucilage formation can commence if the other two environmental factors are also suitable (Altıok and Kayişoğlu, 2015). Climate change-related warming worsens the situation, as warmer and slower seas are favorable for mucilage formation. The water temperature in Marmara has increased by 2 to 2.5 degrees Celsius over the past 20 years, above the global average.

A causal loop diagram representing the main system elements (components) for the dynamic mechanism for the mucilage problem in the Sea of Marmara is given in Figure 6. As summarized in Figure 6, mucilage formation is an event triggered by an increase in light and temperature. If the nitrogen and phosphorus needed as a nutrient source are present in the environment, phytoplanktons will rapidly multiply and release mucilage. In addition, some minor elements such as iron can contribute to the formation of mucilage by playing a catalyst role in the nitrogen cycle. Overfishing reduces the number of fish that feed on phytoplankton, thus increasing mucilage production. As shown in Figure 6, the amount of dissolved oxygen will be very high in the first stage when phytoplanktons multiply rapidly. However, because of bacterial decay, there will be a rapid decrease in oxygen in the following phases. This condition will have a negative impact on benthic species, as well as the economy, as fisherman will not be able to hunt. Visual pollution will also have an adverse effect on the tourism industry. Low dissolved oxygen levels, aquatic creature death, and food chain disturbance are all ecological implications of mucilage. 
All in all, the mucilage problem has serious negative consequences for the ecology, human health, and the economy. Algal toxins can cause allergic reactions and other health problems in humans. On the other hand, the loss of recreational income, fisheries, and aquaculture contamination has a negative impact on the economy. Low dissolved oxygen levels, aquatic creature death, and food chain disturbance are all ecological implications of mucilage.

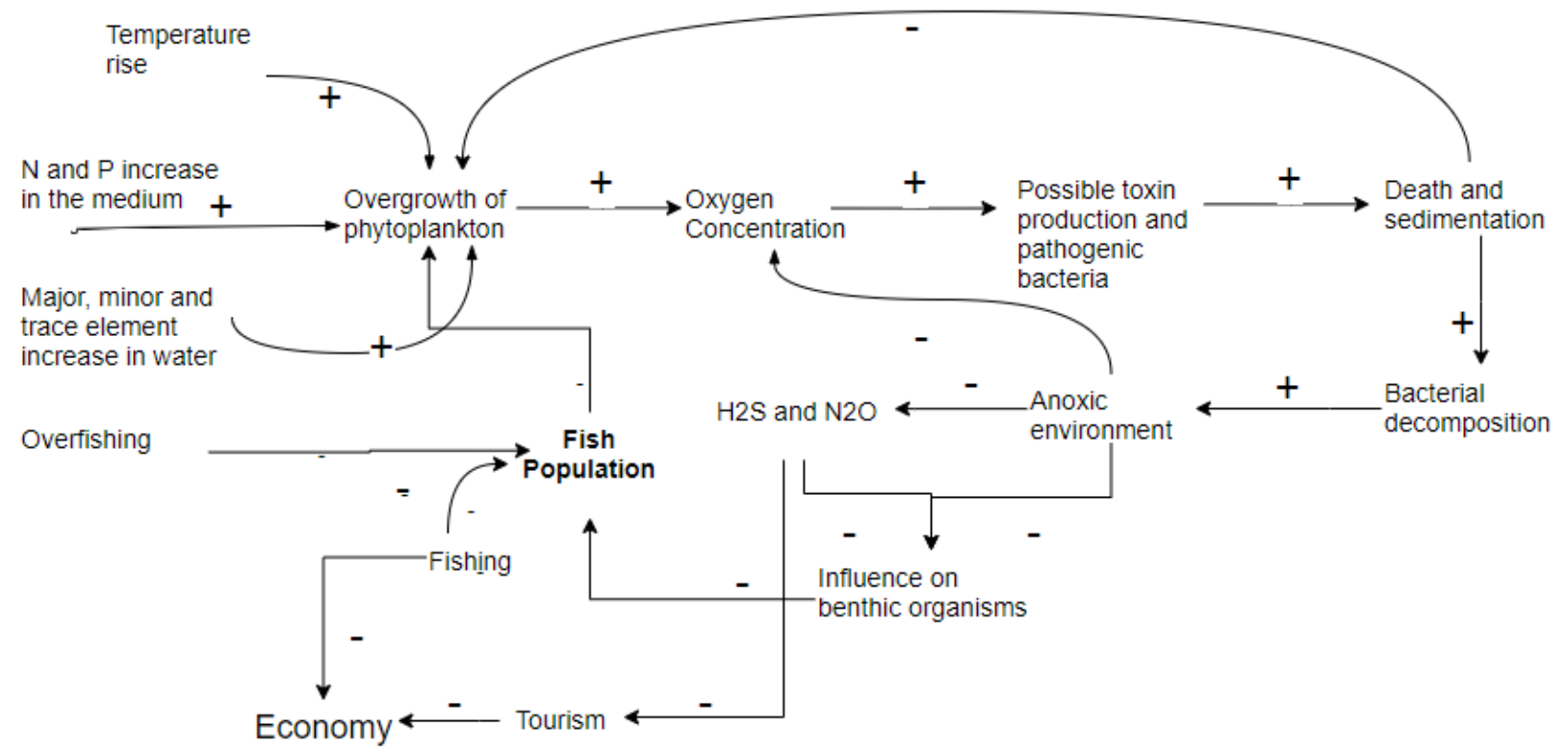

Fig. 6. Causal loop diagram representing the dynamic mechanism for the mucilage problem in the Sea of Marmara

The Sea of Marmara has been widely studied in terms of its physical characteristics (Beşiktepe, 2003; Beşiktepe et al., 2008; Oğuz et al., 1990), but less so in terms of its chemistry (Polat and Tugrul, 1996; Polat and Tugrul, 1995; Tugrul et al., 2002). Several studies have been conducted on the effects of mucilage aggregation on phytoplankton in the Sea of Marmara (Aktan et al., 2008; Tüfekçi et al., 2010; Balkıs et al., 2011) and its effect on zooplankton (İşinibilir-Okyay et al., 2015). A summary of recent related studies on the presence of mucilage in the Sea of Marmara is given in Table 3.

During the mucilage event that occurred in the Sea of Marmara from October 2007 to February 2008, the composition and number of phytoplankton and environmental factors were evaluated by Tüfekçi et al. (2010). In the mucilage formation, the most abundant species were reported as Gonyaulax fragilis, Skeletonema costatum, Cylindrotheca closterium and Thalassiosira rotula (Taş et al., 2016; Tüfekçi et al., 2010; Balk1s et al., 2011). G. fragilis had the highest abundance of $18.2 \times 103$ cells $\mathrm{L}^{-1}$, whereas C. closterium had $114 \times 10^{3}$ cells $\mathrm{L}^{-1}$. These species that are thought to be responsible for mucilage formation in the Sea of Marmara are shown in Figure 7.

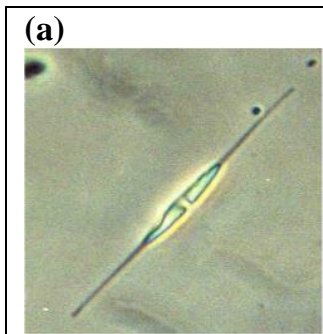

(c)

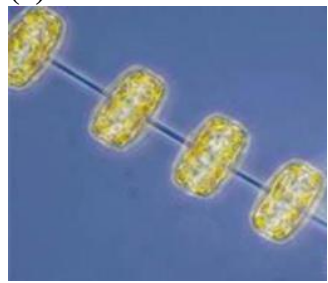

Fig. 7. Some phytoplankton species thought to influence mucilage formation in the Sea of Marmara (a. Cylindrotheca closterium, b. Gonyaulax fragilis, c. Thalassiosira rotula, d. Skeletonema costatum) (Ediger et al., 2016; Taş et al., 2016; Tüfekçi et al., 2010; Balkıs et al., 2011). 
Table 3. A summary of recent related studies on the presence of mucilage in the Sea of Marmara.

\section{Reference Field Highlights}

Zingone et Marine Freshwater

al. (2021) Biology

$\begin{array}{ll}\text { Toklu- } & \text { Biology } \\ \text { Alicli et al. } & \\ (2021) & \end{array}$

Balkıs- Oceanography

Ozdelice et

al. (2020)

$\begin{array}{ll}\begin{array}{l}\text { Toklu- } \\ \text { Alicli et al. } \\ (2020)\end{array} & \begin{array}{l}\text { Marine Freshwater } \\ \text { Biology, } \\ \text { Oceanography }\end{array} \\ & \\ \begin{array}{l}\text { Tas et al. } \\ (2020)\end{array} & \begin{array}{l}\text { Fisheries; } \\ \text { Geosciences, } \\ \text { Multidisciplinary; } \\ \text { Marine Freshwater } \\ \text { Biology; } \\ \text { Oceanography }\end{array} \\ & \begin{array}{l}\text { Oceanography } \\ \text { Ergül et al. } \\ (2018)\end{array} \\ & \begin{array}{l}\text { Marine Freshwater } \\ \text { Biology }\end{array} \\ \end{array}$

- The spatial distribution and implications of toxic marine microalgal species on the Mediterranean sea, including the Black Sea, Marmara Sea, coastal lagoons and transitional water, were assessed on the basis of the two databases that have been compiled in the Ocean Biogeographic Information System.

- In the summer, mucilages and discolouration have a significant effect on tourism. The main dangers for HAB stem from significant microalgae developments and the consequences for tourism that form the greatest component of the sea economy along the coast, due to the poor coastal water quality.

- In the Sea of Marmara (Gulf of Bandirma), the zooplankton community and their environmental variabilities were periodically analyzed for 2 years. The zooplankton's diversity in the Bandirma Gulf in the first sampling year was higher and declined in the second sampling year due to the mucilage impact.

- In the period Of november 2006 to August 2008, seasonal variations in phytoplankton communities were explored for certain environmental factors in coastal waters of the Erdek Gulf.

- 95 species were identified from 6 distinct algae groups.

- Two species were discovered for the first time in Turkish coastal waters, while one species was discovered for the first time in the Sea of Marmara.

- Synechococcus was studied in the Gulfs of Bandirma and Erdek, where water samples were collected during a period of high mucilage formation (between August 2007 and August 2008).

- The vertical distribution of Synechococcus was influenced by the two-layered structure of the Sea of Marmara, with highest abundance in the upper layers and low abundance in the deeper layers of both gulfs.

- Synechococcus is temperature sensitive but other environmental factors were found to affect the abundance distribution more than temperature.

- From January 2004 to December 2007, temporal fluctuations in phytoplankton composition in the northeastern Sea of Marmara were explored in combination with physico-chemical factors.

- During the study period, the presence of potentially toxic species and a mucilage event were also observed.

- The reported modifications in the zooplankton population during the same period, as well as a substantial decline in the number of species and the diversity index after June 2007, indicate potential cascade impacts on the pelagic ecosystem of the Sea of Marmara.

- $\quad$ Six samples were taken in Izmit Bay (Marmara Sea), where a series of red tides were reported in 2015.

- When the findings are compared to those from other research in surrounding Mediterranean seas, it becomes clear that the Izmit Bay had the most extreme dangerous dinoflagellate bloom in recent years and needs additional protection measures.

- This case also shows how pollutants accumulating in sediment can have long-term consequences for enclosed marine ecosystems.

- The main goal of this research was to determine how a zooplankton population evolves during Liriope tetraphylla blooms and mucilage formation in the Sea of Marmara.

- Jellyfish species play a crucial role in plankton community reconfiguration, and Liriope induced a temporal regime change from a crustacean-controlled to a jellyfish-controlled system in the Sea of Marmara. Following the Liriope rise, there was a quick fall in the abundance of the most important zooplankton species 
- The decrease of zooplankton and the disastrous impacts of mucilage on pelagic ecosystems and socioeconomics indicated that the already disturbed Marmara ecosystem was vulnerable to changes in predator concentrations.

Altıok and Fisheries;

Kayişoğlu Geosciences,

(2015) Multidisciplinary;

Marine Freshwater

Biology;

Oceanography

Okyar et Zoology

al. (2015)

- The distribution of temperature and salinity, as well as volume fluxes, along the Strait of Istanbul were studied using long-term monthly temperature-salinity time series obtained from both ends of the strait.

- The cycle of upper layer temperature, with minimums in February and maximums in August, is primarily influenced by river discharge into the Western Black Sea, the annual cycle of upper layer salinity, with minimums in April and September, is primarily influenced by air temperature with a near monthly phase shift.

- Flow obstructions are the main cause of seasonal fluctuations in the lower layer temperature and salinity in the Strait of Istanbul.

- At the 2008 Marmara Sea mucilage event (April-December 2008), the composition and abundance of zooplankton, as well as the relevant environmental variables, were studied.

- As a result, 46 different zooplanktonic taxa have been reported.

- The most abundant groups in general were copepods and cladocerans. Mnemiopsis leidyi possessed a strong seasonality, and its abundance was linked to temperature and salinity changes. Acartia clausi and Penilia avirostris were the most important species, though they did not reach their autumn peak.

- The 2008 mucilage event in the Marmara Sea resulted in dramatic changes in zooplankton abundance and community structure.

Balkis et Marine Freshwater al. (2011) Biology

Tüfekçi, et Biology

al. (2010)
- The goal of this study was to determine which environmental variables and organisms were responsible for the mucilage production in the Marmara Sea.

- Between January and June 2008, samples were gathered from one sampling station on the Buyukada Island coastline at seven depths $(0.5-30 \mathrm{~m})$.

- 62 phytoplankton species (from 5 different groups) were reported. The limiting nutrient was nitrogen, and the amount of silica available was sufficient to allow the formation of diatoms.

- During a mucilage event in the Sea of Marmara, the composition and abundance of phytoplankton, as well as the environmental factors, were studied.

- Gonyaulax fragilis, Skeletonema costatum, and Cylindrotheca closterium were shown to be abundant mucilage producers. Thallassiosira rotula was found in significant quantities as well. The high level of organic carbon in mucilage (24\%) and the surrounding waters support the theory that the event was caused by phytoplankton cellular exudates that were organically rich. 


\section{Recommendations}

As explained above, the factors causing mucilage are increased temperature, the sea's stagnant nature, and the nutrient load discharged into the sea. Since it is difficult/impossible to change environmental factors, what needs to be done is to prevent pollutant discharge into the sea. The long-term and ultimate solution to this problem is integrating existing treatment plants with advanced treatment technologies. On the other hand, various short-term measures that can be used for dealing with the mucilage in the Sea of Marmara are being considered and listed below:

- Stop Fishing (The single-celled organisms that make up the mucilage are the primary food source of fish. Therefore, stopping fishing can lead to fish population growth and the natural elimination of mucilage).

- Eliminating mucilage with beneficial bacteria (Application of local bacterial isolates that were isolated from the seas for 20 years to the mucilage covered area) (Altuğ, 2021).

- Reactive oxygen dosing (By determining the temporal and spatial distribution of mucilage, reactive oxygen dosing with mobile platforms on the shores of Marmara).

- Collecting mucilage on the surface (A clean-up effort with teams skimming and removing some of the mucilage from the water).

Some municipalities collect mucilage layers on the surface. This effort can reduce visual pollution; increase the transmission of light and macroalgae photosynthesis, contributing to a small amount of dissolved oxygen. This cannot, however, be considered a promising solution for the mucilage problem.

The mucilage in the past either dispersed naturally, were collected from the surface with various tools, or disappeared from view by sinking to the bottom of the sea. Hence, another opinion is that waiting out might solve the problem. However, longer-term measures are needed to cope with the growing dimension of the problem. If the issue isn't approached more directly, the problem will undoubtedly come back in the next few years as the seas get warmer.

In addition, studies are carried out by many scientists on whether the current mucilage can provide a beneficial use. Investigations are continuing on the use of mucilage in biofuel applications or its use in the cosmetics industry, feed industry, or as agricultural fertilizer after purification.

To eliminate mucilage, the Ministry of Environment and Urbanization has announced a 22-point action plan. It is suggested that the existing wastewater treatment plants in the region should be converted into advanced biological treatment facilities to eliminate nitrogen and phosphorus effectively. The implementation of advanced purification technologies is of critical importance indeed as there are around 100 deep-sea discharge points in the region. Since there are about 100 deep-sea discharge points in the region, using advanced purification technologies is of critical importance. In addition, encouragement on the reuse of treated wastewater to a greater extent is considered. The action plan will periodically monitor the streams that transfer agricultural chemicals to the sea.

\section{Conclusion}

Although studies have provided us with necessary information on the structure and formation of mucilage, it is crucial to be aware that the mechanism is very complex, and this formation is not the result of a single cause. The information gathered in the field studies indicates that rising seawater temperatures and particularly human-induced pressure (domestic and industrial waste, inadequate treatment levels, overfishing, coastal destruction, heavy ship traffic, etc.) trigger mucilage formation.

Mucilage formation causes even more ecological deterioration (oxygen depletion in bottom waters, mass death of fish, marine invertebrates and plants, etc.). Plants and animals' death on the seafloor is inevitable due to sudden and intense mucilage development. This decay may lead to the rapid consumption of oxygen in the environment and the emergence of conditions such as the reduction of dissolved oxygen concentrations, which are at levels that will allow living things to live in the sea, to low levels (hypoxic) or their complete depletion (anoxic conditions). Thus, the resilience of the ecosystem, that is, its capacity to renew itself, decreases and is seriously damaged. The potential role of mucilage in the transmission of bacteria and viruses should also be taken into consideration.

With respect to management, point source inputs from sewage treatment plants can be successful reduced by putting effective treatment plants into operation. The control of inputs from diffuse sources remains, however, a challenging problem.

The conclusion is that, in the absence of efficient ecosystem-based management of both point and diffuse sources of nitrogen and phosphorus, the formation of mucilage is likely to continue to increase. The complexity of the issue calls for continuous, integrated research and monitoring and repeated evaluations of the load and effects of nutrients. These must be guided by ongoing collaborations between scientific experts, politicians, managers, and the public.

\section{Acknowledgements}

Başak Savun-Hekimoğlu is a post-doctoral researcher at Istanbul University, Institute of Marine Sciences and Management. The author is thankful to the Istanbul University Research Fund (BAP) for post-doctoral scholarship granted with an identity number MAB-201934967. We would like to thank the R/V Alemdar II staff 
who personally took part in the studies in which we obtained some current findings in this study, and the academic staff of the institute who provided scientific and financial contributions to the expedition.

\section{References}

Altuğ, G. (2021). Unpublished Data

Aktan, Y., Topaloğlu, B. (2011). First record of Chrysophaeum taylorii Lewis Bryan and their benthic mucilaginous aggregates in the Aegean Sea (Eastern Mediterranean). J. Black Sea/Medit. Environ, 17(2), 159-170.

Aktan, Y., Dede, A., Ciftci, P.S. (2008). Mucilage event associated with diatoms and dinoflagellates in Sea of Marmara, Turkey. Harmful Algae News, IOCUNESCO, 1-3.

Alldredge, A. L., Crocker, K. M. (1995). Why do sinking mucilage aggregates accumulate in the water column?. Science of the total environment, 165(1-3), $15-22$.

Altıok, H., Kayişoğlu, M. (2015). Seasonal and interannual variability of water exchange in the Strait of Istanbul. Mediterranean Marine Science, 16(3), 644-655.

Artüz O.B., Artüz M.L. The project "Changing Oceanographic Conditions of the Sea Of Marmara" MAREM (Marmara Environmental Monitoring). GFCM Workshop on Algal and Jellyfish Blooms in the Mediterranean and Black Sea 6 th /8th October 2010, Istanbul, Turkey.

Azam, F. (1998). Microbial control of oceanic carbon flux: the plot thickens. Science, 280(5364), 694-696.

Azam, F., Long, R. A. (2001). Sea snow microcosms. Nature, 414(6863), 495-498.

Balkıs, N., Atabay, H., Türetgen, I., Albayrak, S., Balkıs, H., Tüfekçi, V. (2011). Role of single-celled organisms in mucilage formation on the shores of Buyukada Island (the Marmara Sea). Marine Biological Association of the United Kingdom. Journal of the Marine Biological Association of the United Kingdom, 91(4), 771.

Balkıs-Ozdelice, N., Durmus, T., Toklu-Alicli, B., Balci, M. (2020). Phytoplankton composition related to the environmental conditions in the coastal waters of the Gulf of Erdek.

Berthon, J. F., Zibordi, G., Hooker, S. B. (2000). Marine optical measurements of a mucilage event in the northern Adriatic Sea. Limnology and oceanography, 45(2), 322-327.

Beşiktepe, Ş. T. (2003). Density currents in the two-layer flow: an example of Dardanelles outflow. Oceanologica Acta, 26(3), 243-253.

Beşiktepe, Ş. T., Lermusiaux, P. F., Robinson, A. R. (2003). Coupled physical and biogeochemical datadriven simulations of Massachusetts Bay in late summer: real-time and postcruise data assimilation. Journal of Marine Systems, 40, 171-212.

Beşiktepe, S., Ryabushko, L., Ediger, D., Yılmaz, D., Zenginer, A., Ryabushko, V., Lee, R. (2008). Domoic acid production by Pseudo-nitzschia calliantha Lundholm, Moestrup et Hasle (bacillariophyta) isolated from the Black Sea. Harmful Algae, 7(4), 438-442.
Bianchi, G. (1746). Notizie sulla vasta fioritura algale del 1729. Raccolta d'opuscoli scientifici e filologici, 34, 256-257.

Bidle, K. D., Azam, F. (1999). Accelerated dissolution of diatom silica by marine bacterial assemblages. Nature, 397(6719), 508-512.

Burak, S., Bilge, A. H., Ülker, D. (2021). Assessment and simulation of water transfer for the megacity Istanbul. Physical Geography, 1-25.

Burak, S., Unlu, S., Gazioğlu, C. (2009). Environmental stress created by chemical pollution in the Marmara sea (Turkey). Asian Journal of Chemistry, 21(4), 3166-3174.

Çardak, M., Altuğ, G., Türetken, P. S. (2015). Variations of Culturable and Metabolically Active Bacteria in a Stratified Water Column: The Example of Istanbul and Çanakkale Straits, Turkey. International Journal of Environmental Research, 9(4), 1333-1340.

Cardak, M., Özbek, E. Ö., Kebapçioğlu, T. (2015). Seasonal abundance and diversity of culturable heterotrophic bacteria in relation to environmental factors in the Gulf of Antalya, Eastern Mediterranean, Turkey. World Journal of Microbiology and Biotechnology, 31(4), 569-582.

Caronni, S., Calabretti, C., Cavagna, G., Ceccherelli, G., Delaria, M. A., Macri, G., ... Panzalis, P. (2017). The invasive microalga Chrysophaeum taylorii: Interactive stressors regulate cell density and mucilage production. Marine environmental research, 129, 156-165.

Cozzi, S., Ivančić, I., Catalano, G., Djakovac, T., Degobbis, D. (2004). Dynamics of the oceanographic properties during mucilage appearance in the Northern Adriatic Sea: analysis of the 1997 event in comparison to earlier events. Journal of Marine Systems, 50(3-4), 223-241.

Danovaro, R., Umani, S. F., Pusceddu, A. (2009). Climate change and the potential spreading of marine mucilage and microbial pathogens in the Mediterranean Sea. PLoS One, 4(9), e7006.

De Lazzari, A., Berto, D., Cassin, D., Boldrin, A., Giani, M. (2008). Influence of winds and oceanographic conditions on the mucilage aggregation in the Northern Adriatic Sea in 2003-2006. Marine Ecology, 29(4), 469-482.

Del Negro, P., Crevatin, E., Larato, C., Ferrari, C., Totti, C., Pompei, M., ... Umani, S. F. (2005). Mucilage microcosms. Science of the Total Environment, 353(1-3), 258-269.

Ediger, D., Beken, Ç., Yüksek, A., Tuğrul, S. (2016). Eutrophication in the Sea of Marmara. The Sea of, 723.

Ergül, H. A., Aksan, S., İpşiroğlu, M. (2018). Assessment of the consecutive harmful dinoflagellate blooms during 2015 in the Izmit Bay (the Marmara Sea). Acta Oceanologica Sinica, 37(8), 91-101.

Flander-Putrle, V., Malej, A. (2008). The evolution and phytoplankton composition of mucilaginous aggregates in the northern Adriatic Sea. Harmful Algae, 7(6), 752-761.

Fukao, T., Kimoto, K., Yamatogi, T., Yamamoto, K. I., Yoshida, Y., Kotani, Y. (2009). Marine mucilage in Ariake Sound, Japan, is composed of transparent 
exopolymer particles produced by the diatom Coscinodiscus granii. Fisheries Science, 75(4), 10071014.

Funari, E., Ade, P. (1999). Human health implications associated with mucilage in the northern Adriatic Sea. Annali dell'Istituto superiore di sanità, 35(3), 421-425.

Giani, M., Savelli, F., Berto, D., Zangrando, V., Ćosović, B., Vojvodić, V. (2005). Temporal dynamics of dissolved and particulate organic carbon in the northern Adriatic Sea in relation to the mucilage events. Science of the Total Environment, 353(1-3), 126-138.

Gigliotti, A. (2013). Extracting temporal and spatial distributions information about marine mucilage phenomenon based on Modis satellite images; a case study of the Tyrrhenian and the Adriatic Sea, 20102012 (Doctoral dissertation).

Gotsis-Skretas, O. (1995). Mucilage appearances in Greek waters during 1982-1994. Science of the total environment, 165(1-3), 229-230.

Herndl, G. J., Peduzzi, P. (1988). The ecology of amorphous aggregations (Marine Snow) in the Northern Adriatic Sea. Marine Ecology, 9(1), 79-90.

İşinibilir-Okyar, M., Üstun, F., Orun, D.A. (2015) Changes in abundance and community structure of the zooplankton population during the 2008 mucilage event in the northeastern Marmara Sea. Turkish Journal of Zoology 39: 28-38.

Kiørboe, T., Jackson, G. A. (2001). Marine snow, organic solute plumes, and optimal chemosensory behavior of bacteria. Limnology and Oceanography, 46(6), 1309-1318.

Kraus, R., Supić, N. (2015). Sea dynamics impacts on the macroaggregates: A case study of the 1997 mucilage event in the northern Adriatic. Progress in oceanography, 138, 249-267.

Lancelot, C. (1995). The mucilage phenomenon in the continental coastal waters of the North Sea. Science of the total environment, 165(1-3), 83-102.

MacKenzie, L., Sims, I., Beuzenberg, V., Gillespie, P. (2002). Mass accumulation of mucilage caused by dinoflagellate polysaccharide exudates in Tasman Bay, New Zealand. Harmful Algae, 1(1), 69-83.

Maryam, B., Büyükgüngör, H. (2019). Wastewater reclamation and reuse trends in Turkey: Opportunities and challenges. Journal of Water Process Engineering, 30, 100501.

Mecozzi, M., Pietrantonio, E., Di Noto, V., Pápai, Z. (2005). The humin structure of mucilage aggregates in the Adriatic and Tyrrhenian seas: hypothesis about the reasonable causes of mucilage formation. Marine chemistry, 95(3-4), 255-269.

Oğuz, T., Özsoy, E., Latif, M. A., Sur, H. I., Ünlüata, Ü. (1990). Modeling of hydraulically controlled exchange flow in the Bosphorus Strait. Journal of Physical Oceanography, 20(7), 945-965.

Oğuz, T., Özsoy, E., Latif, M. A., Sur, H. I., Ünlüata, Ü. (1990). Modeling of hydraulically controlled exchange flow in the Bosphorus Strait. Journal of Physical Oceanography, 20(7), 945-965.

Okuş, E., Aslan-Yılmaz, A., Yüksek, A., Taş, S., Tüfekçi, V. (2002). Nutrient distribution in the
Bosphorus and surrounding areas. Water science and technology, 46(8), 59-66.

Okyar, M. İ., Üstün, F., Orun, D. A. (2015). Changes in abundance and community structure of the zooplankton population during the 2008 mucilage event in the northeastern Marmara Sea. Turkish Journal of Zoology, 39(1), 28-38.

Özalp, H. B. (2021). First massive mucilage event observed in deep waters of Çanakkale Strait (Dardanelles), Turkey. Journal of the Black Sea/Mediterranean Environment, 27(1) 49-66.

Özsoy, E., Çağatay, M.N., Balkıs, N., Balkıs, N., Öztürk, B. (Eds.) (2016). The Sea of Marmara; Marine Biodiversity, Fisheries, Conservation and Governance. Turkish Marine Research Foundation (TUDAV), Publication No: 42, Istanbul, TURKEY.

Öztürk, A., Yarci, C., Ozyigit, I. I. (2017). Assessment of heavy metal pollution in Istanbul using plant (Celtis australis L.) and soil assays. Biotechnology Biotechnological Equipment, 31(5), 948-954.

Peduzzi, P., Weinbauer, M. G. (1993). Effect of concentrating the virus-rich $2-2 \mathrm{~nm}$ size fraction of seawater on the formation of algal flocs (marine snow). Limnology and Oceanography, 38(7), 15621565.

Polat, C., Tugrul, S. (1996). The annual influxes of phosphorus, nitrogen and organic carbon into the Marmara Sea from the Black Sea and Istanbul wastes. Oceanographic Literature Review, 4(43), 411.

Polat, S. Ç., Tugrul, S. (1995). Nutrient and organic carbon exchanges between the Black and Marmara Seas through the Bosphorus Strait. Continental Shelf Research, 15(9), 1115-1132.

Precali, R., Giani, M., Marini, M., Grilli, F., Ferrari, C. R., Pečar, O., Paschini, E. (2005). Mucilaginous aggregates in the northern Adriatic in the period 1999-2002: typology and distribution. Science of the Total Environment, 353(1-3), 10-23.

Rinaldi, A., Vollenweider, R. A., Montanari, G., Ferrari, C. R., Ghetti, A. (1995). Mucilages in Italian seas: the Adriatic and Tyrrhenian seas, 1988-1991. Science of the Total Environment, 165(1-3), 165183.

Simon, M., Grossart, H. P., Schweitzer, B., Ploug, H. (2002). Microbial ecology of organic aggregates in aquatic ecosystems. Aquatic microbial ecology, 28(2), 175-211.

Taş, S., Ergül, H. A., Balkıs, N. (2016). Harmful algal blooms (HABs) and mucilage formations in the Sea of Marmara. The Sea of, 768.

Taş, S., Kus, D., Yılmaz, I. N. (2020). Temporal variations in phytoplankton composition in the northeastern Sea of Marmara: potentially toxic species and mucilage event. Mediterranean Marine Science, 21(3), 668-683.

Taş, S., Yılmaz, I. N. (2015). Potentially harmful microalgae and algal blooms in a eutrophic estuary in Turkey. Mediterranean Marine Science, 16(2), 432443.

Tassan, S. (1993). An algorithm for the detection of the White-Tide ("mucilage") phenomenon in the Adriatic 
Sea using AVHRR data. Remote sensing of environment, 45(1), 29-42.

Toklu-Alicli, B., Balkıs-Ozdelice, N., Durmus, T., Balci, M. (2021). Relationship between environmental factors and zooplankton diversity in the Gulf of Bandirma (the Sea of Marmara). Biologia, 76(6), 1727-1736.

Toklu-Alicli, B., Polat, S., Balkıs-Ozdelice, N. (2020), Temporal variations in the abundance of picoplanktonic Synechococcus (Cyanobacteria) during a mucilage event in the Gulfs of Bandirma and Erdek. Estuarine, Coastal and Shelf Science, 233, 106513.

Tüfekçi, V., Balkıs, N., Beken, Ç. P., Ediger, D., Mantikci, M. (2010). Phytoplankton composition and environmental conditions of the mucilage event in the Sea of Marmara. Turkish Journal of Biology, 34(2), 199-210.

Tugrul, S., Beşiktepe, T., Salihoglu, I. (2002). Nutrient exchange fluxes between the Aegean and Black Seas through the Marmara Sea. Mediterranean Marine Science, 3(1), 33-42.

Umani, S. F., Del Negro, P., Larato, C., De Vittor, C., Cabrini, M., Celio, M., ... Azam, F. (2007). Major inter-annual variations in microbial dynamics in the Gulf of Trieste (northern Adriatic Sea) and their ecosystem implications. Aquatic Microbial Ecology, 46(2), 163-175.

Volterra, L., Conti, M. E. (2000). Algae as biomarkers, bioaccumulators and toxin producers. International Journal of Environment and Pollution, 13(1-6), 92125.

Weinbauer, M. G., Fuks, D., Peduzzi, P. (1993). Distribution of viruses and dissolved DNA along a coastal trophic gradient in the northern Adriatic Sea. Applied and Environmental Microbiology, 59(12), 4074-4082.

Yentur, R. E., Büyükateş, Y., Özen, Ö., Altın, A. (2013). The environmental and socio-economical effects of a biologic problem: Mucilage. Marine Science and Technology Bulletin, 2(2), 13-15.

Yilmaz, I. N. (2015). Collapse of zooplankton stocks during Liriope tetraphylla (Hydromedusa) blooms and dense mucilaginous aggregations in a thermohaline stratified basin. Marine Ecology, 36(3), 595-610.

Zambianchi, E., Calvitti, C., Cecamore, P., D'Amico, F., Ferulano, E., Lanciano, P. (1992). The mucilage phenomenon in the Northern Adriatic Sea, summer 1989: a study carried out with remote sensing techniques. In Marine Coastal Eutrophication (pp. 581-598). Elsevier.

Zingone, A., Escalera, L., Aligizaki, K., FernándezTejedor, M., Ismael, A., Montresor, M., ... Totti, C. (2021). Toxic marine microalgae and noxious blooms in the Mediterranean Sea: A contribution to the Global HAB Status Report. Harmful Algae, 102, 101843. 